\title{
Employment regulation in collective bargaining in Spain
}

\author{
Ramon Alos Moner\#*\#
}

\begin{abstract}
Summary
Concern surrounding employment issues such as job creation, job security and job quality has led to these issues being included in the collective bargaining process in Spain. Nevertheless, there are a number of matters which should receive greater attention from the social partners in future. Of particular importance is the need to co-ordinate collective bargaining in order to make it more flexible, i.e. more adaptable, whilst at the same time providing a stable framework in order to avoid the problems associated with the fragmentation of employment conditions. This article looks at the evolution of collective bargaining on employment issues since the end of the 1970s, as well as the social partners' main bargaining demands with regard to these issues, and their most prominent characteristics.
\end{abstract}

\section{Sommaire}

\section{Zusammenfassung}

\section{The first steps towards collective bargaining on employment issues [LEVEL 1]}

Employment issues began to be included in the collective bargaining process in Spain at the end of the 1970s. The severe economic crisis which the country was going through at the time led to major restructuring within companies, and that in turn led to industrial disputes, but also to negotiations. This was a time of very high unemployment, and as a result, for several years unemployment became the most important issue for Spanish society. Against this background, there was an intense period of negotiations between employers and trade unions from 1979 to $1985 \# 1 \#$, which resulted in the signing of various centrally_-agreed social pacts in which employment played a key role, either in terms of promoting job creation or in terms of assistance for the unemployed. Not all the promises made during these negotiations were kept, however, especially with regard to job creation. The result was widespread disenchantment and the eventual decision of the trade unions to pull out of the negotiations altogether. This marked the beginning of a new phase in Spanish industrial relations characterised by frequent disputes and deep mistrust between the social partners, culminating in the dramatic general strike of 14 December $1988_{2}$, which was in part sparked off by discontent with regard to employment issues.

During the economic crisis of the early 1990s, the problem of employment returned, as did concern about employment issues. The trade unions entered into either bipartite or tripartite negotiations at different levels, from local level to national level. Between 1992 and 1993, agreements to promote 
employment were signed in nearly all of Spain's autonomous regions, although in practice their impact tended to be limited. A small number of agreements were also signed at local authority level aimed at attracting companies to the area in question.

Shortly afterwards, in 1994, the government introduced a labour law reform which was to have far-reaching effects on future negotiations on employment issues (del Rey 1998). There are four aspects of this reform which are of interest in our context (Alós et al. 1994):

- it reduced the role and scope of legislation,

- it gave an increased legal role to collective bargaining and individual negotiations too,

- it made collective bargaining more flexible by recognising company-level 'pacts'\#2\#, and

- it gave employers greater scope to determine employment conditions.

As a result of this reform, many workers found themselves facing the problem of how to respond to decisions regarding employment issues that companies were now able to take thanks to the greater legal room for manoeuvre at their disposal. For the trade unions, one way of responding was via negotiation, and consequently they sought to restrict employers' room for manoeuvre in collective agreements and company-level 'pacts' on issues such as temporary jobs, which, as is widely known, account for over $30 \%$ of the average Spanish company's workforce. One problem with this approach, however, is that by reaching this type of agreement, the workers' representatives were effectively legitimising employers' use of temporary contracts (Escudero 1997). This type of negotiations, which had not been seen before, led to a split between the leadership of the main trade union confederations on the one hand, and elected workers representatives and trade union representatives at company level on the other. Whilst the former were opposed to the unjustified use of temporary contracts, the latter were more concerned with improving the terms of employment of temporary workers, thereby implying that they accepted this type of contract as legitimate (Falguera and López Bulla 1997). It should in any case be pointed out that such agreements have been reached in only a few companies, mainly ones with a unionised workforce where employers have more difficulties in imposing their authority..

\section{Collective bargaining on employment issues after the Interconfederal Agreement for Employment Stability (AIEE) [LEVEL 1]}

The period of economic growth experienced during the second half of the 1990s brought about a significant change in the issues that were of greatest concern to Spanish citizens, with job instability due to temporary contracts joining unemployment at the top of the agenda. Indeed, some employers were even to be heard complaining that the extremely high level of job instability was affecting the stability of consumer behaviour and causing economic uncertainty.

Against this new background, and under the auspices of a conservative government (the Popular Party) under pressure to obtain social 
acceptance\#3\#, employers and trade unions entered into negotiations which culminated in the signing of three major agreements in April 1997. One of these agreements, known as the 'Interconfederal Agreement for Stability in Employment' (AIEE), was designed to achieve a reduction in the level of temporary contracts through the introduction of a new type of permanent contract which reduces the amount of redundancy money that employers have to pay in cases of wrongful dismissal\#4\#. It has also been agreed with the government that companies converting temporary contracts into permanent ones will receive a rebate in employer's social security contributions provided that the conversion of the contracts is handled via collective bargaining.

It can thus be said that the AIEE has done a lot to promote the negotiation of employment issues, both in sectoral collective agreements and in plant-level 'pacts'. Furthermore, the AIEE has come to be regarded as a reference point for negotiations at autonomous region level or below. This process of decentralised negotiations between employers and trade unions has been encouraged still further by the recent EU employment guidelines.

One characteristic shared by the majority of the agreements on employment issues that have been negotiated since 1997 is the tendency to offer more stable employment terms in exchange for flexibility in working hours and tasks performed at work (Martín Artiles et al. 2000). This trade-off has formed the basis of a wide range of agreements. What 'more stable employment terms' has meant is employers committing to limit their use of temporary workers or only to use them in certain circumstances or for certain types of job, as well as providing assurances regarding the extent to which they will use temporary employment agencies, and also stabilising employment terms by converting temporary contracts into permanent ones. All of these promises are intended to increase the security of employees. As far as the employee side is concerned, they have accepted a greater degree of multi-tasking and more flexibility as regards working hours. Multi-skilling has been promoted so that workers can perform a number of different tasks, and new job classifications have also been introduced with a reduced number of professional categories and a high level of mobility within categories.

As far as flexibility of working hours is concerned, it is necessary to distinguish between atypical working hours and flexitime. Atypical working hours refers to the introduction of new shifts, working at weekends and other types of unconventional work patterns. Flexitime, on the other hand, refers to the ability to vary the number of hours worked per day or per week, as long as the total number of hours worked per year remains the same. In other words, an annual hours total is established, and employers can decide, freely or with certain restrictions, how these hours are divided up in order to best meet production requirements, for example by increasing the number of hours worked on certain days or by calling people in to work on Saturdays or public holidays. In some cases, the decision to apply flexitime is taken exclusively by management on the basis of the prevailing set of circumstances, whereas in others workers' representatives are involved. Their participation may be restricted to information and consultation, or it may also be that their explicit 
agreement is required. Workers on flexitime usually receive advance warning of changes to their working hours, although the notice they receive is almost always small or minimal. There are also a limited number of examples of workers being compensated for having to work unconventional hours, and a maximum number of hours that can be worked per day is also established in some cases (CC.OO. 2000, CEOE 2001, UGT 2001).

Other employment-related issues, such as vocational training, have received some attention in collective bargaining rounds. However, despite its being one of the trade unions' top priorities, there have been hardly any agreements on the reduction of working hours. Subcontracting and people working from home are two further issues of acknowledged importance which have not yet received the attention they deserve in collective negotiations, as demonstrated by the fact that few agreements have been reached that take them into account\#5\#.

Table 1 provides a summary of the social partners"- main employment-related demands that are currently covered by collective bargaining.

Table 1. Main employment-related demands covered by collective bargaining

Trade union demands:

Maintaining employment levels/job creation

More stable contracts

Restrictions on use of flexible contract types

Restrictions on subcontracting

Restrictions on flexitime

Guarantees regarding multitasking

Training

Employer demands:

Reduction of labour costs

More flexible working hours

More flexible work practices

Retraining of workers

Motivation as a means of control

Corporate image

Acceptance of change

Government demands:

Keep wages in check

Job creation and reduction of unemployment

Training and retraining

Prevention of social conflict

Social recognition

\section{Evaluation [LEVEL 1]}

It is fair to say that employment has not only become one of the issues that are usually included in collective negotiations, but that in some cases it has even been elevated to the status of a key element of such negotiations. This 
has been interpreted as meaning that collective bargaining has been enriched, not only because it covers a wider range of issues, but also in qualitative terms. It is true that collective bargaining on employment issues can encourage negotiations that are not restricted to pay, opening the door to greater influence on matters such as job security, job quality, helping people into work, working hours, vocational training, retraining, etc. However, it should be remembered that although the prospects in this respect are important, they nevertheless remain limited.

In the 1990s, productivity was replaced by competitiveness in the language used by employers, and this terminology has been introduced into collective bargaining on employment issues. However, the implications of this go beyond a mere change in terminology. Whilst productivity is something which is at least partly dependent on the decisions of the people who are directly involved in production, a company's competitiveness is not solely determined by what these people do. What this means is that by tying employment, working time, tasks to be performed or wages to a company's competitiveness, workers are made into the victims of the market's unpredictability, or even made to appear responsible for their own employment situation.

One consequence of collective bargaining on employment issues is that it leads to a broadening of social dialogue in its different levels, resulting in a significant deepening of relations between the social partners. One visible outcome of this is the emergence of a climate of greater knowledge and trust among the social partners, something which could gel into a culture of dialogue, creating a promising basis for future negotiations with repercussions that could extend beyond purely employment-related matters. This does not mean the end of industrial disputes or clashes of interests between the social partners, but it does point to a greater readiness to resolve disputes by negotiation.

One of the main characteristics of collective bargaining on employment issues is a lack of co-ordination, something which constitutes a widespread problem, although there are some indications of a trend towards greater internal coordination by the various social partners, particularly in the case of the trade unions and to a lesser extent also on the part of employers' organisations. The same cannot be said of co-ordination between the different levels of government, which is virtually non-existent, although some measure of coordination of actions has been provided by the European guidelines on employment policy or by major agreements between the state, employers and trade unions, such as the AIEE. Nevertheless, there has been virtually no coordination between regional and local initiatives and the National Employment Action Plan (Aragón et al. 2000). There has been some very limited centralisation of collective agreements with a view to reducing their extremely fragmented nature (Consejo Económico y Social 2001). In a very few cases (for example in the chemical sector), sectoral collective agreements do include clauses that allow for company-level circumstances to be taken into account in the implementation of the agreement, and in these cases it is possible to talk of co-ordinated negotiation of collective agreements. The 
negotiation of company-level 'pacts' on employment issues is even less coordinated and more fragmented, lacking any co-ordination mechanism at all except for whatever efforts may happen to be made by trade unions or employers' associations in specific areas.

The inadequate co-ordination of collective bargaining and the prevalence of company-level 'pacts' on employment issues can result in fragmentation and segmentation. In other words, it can create or consolidate significant differences between the employment terms of different groups of workers, for example between permanent and temporary workers when a dual salary scale is introduced which is not temporary in nature; or between workers who work conventional hours and have considerable freedom to determine their working time and workers who are forced to be available for work at almost any time or to work atypical or irregular hours; or between the workers of companies where it is possible to negotiate more favourable employment terms and the workers of companies, small or otherwise, where this is more difficult or impossible. All of the above scenarios are possible outcomes of collective bargaining on employment issues, which serves to demonstrate its limitations if it is not co-ordinated and regulated at sectoral or national levels, and with labour legislation that guarantees employment standards for all companies and all workers.

The signing of company-level 'pacts' on employment issues throughout the 1990s appears largely to have been a response to the inflexibility of collective agreements which limit employers' ability to determine working hours and how work is organised. The incorporation of flexibility regarding working hours and tasks performed into collective agreements signed at the end of the nineties\#6\# seems to indicate greater reluctance to negotiate 'pacts' on employment issues at company level.

In some cases there appears to be a conflict between the interests and expectations of individuals and the policies of their organisations. Examples of this internal conflict, which appears to be at its greatest in the case of workers, are the 'controversial' agreements with regard to dual salary scales or concerning the acceptance of procedures for automatic redundancies under specific business circumstances. These are conflicts between the trade union leadership and the company-level workers' representatives or shop stewards. There are also conflicts with particular groups of workers. For example, there are cases of trade unions or workers' representatives accepting agreements on flexible or atypical working hours, such as working Saturdays or on public holidays, which have sometimes met with opposition from the workers affected.

Finally, by way of conclusion, when analysing current collective bargaining trends with regard to employment issues it is important not to forget the background of a prolonged period of economic growth during the second half of the 1990s, which has created favourable circumstances for job creation and better and more stable jobs. There can be no doubt that the economic situation has been conducive to the development of collective bargaining on employment issues, enabling the consolidation of a climate of trust and 
dialogue between the social partners. Nevertheless, this begs the question of how the social partners, and in particular employers, would respond to adverse economic conditions. It should not be forgotten that the current consensus in the field of industrial relations is extremely fragile. Similarly, it is important to remember that it takes a long time for a climate of trust to be built up and consolidated, whereas all it needs is for employers to take just one unilateral decision which has a major impact on workers' interests (e.g. redundancies) for all this trust-building to be seriously undermined. This problem, which derives from the economic situation at a given time, is the great risk which is always present in the development of industrial relations.

\section{References}

Alós, R., M. Falguera, P. M.,González, and R. Senra, (1994) La reforma de la legislación laboral, Barcelona: Columna-Conc.

Aragón, J., F. Rocha and J. Torrents (2000) Pactos y medidas de fomento del empleo en las comunidades autónomas, Madrid: Consejo Económico y Social (CES).

CC.OO. (2000) Balance de la negociación colectiva del año 2000.

CEOE (2001) 'Balance de la Encuesta de CEOE sobre Negociación Colectiva 2000', Informes y Estudios, 85.

Consejo Económico y Social (2001) Economía trabajo y sociedad. España 2000. Memoria sobre la situación socioeconómica y laboral, Madrid: CES.

Del Rey, S. (ed.) (1998) La negociación colectiva tras la reforma laboral de 1994, Madrid: CES.

Escudero, R. (1997) 'Adaptabilidad y causalidad de la contratación temporal en la negociación colectiva posterior a la reforma', Relaciones Laborales, 2.

| Falguera, M. and J. L. López Bulla, (1997) El sindicalismo en la encrucijada, Barcelona: Columna-Conc.

Martín Artiles, A., R. Alós, and P. Jódar- (2000) 'Acuerdos de empleo y pactos locales: el pacto por el empleo del Vallés Occidental', Cuadernos de Relaciones Laborales, 17.

UGT (2001) Avance de la negociación colectiva 2001.

\#*\# QUIT research group

Department of Sociology,

Universidad Autónoma, Barcelona

\#1\# These were also the years of the transition to democracy during which the foundations of the current Spanish industrial relations system were laid. \#2\# Nevertheless, company 'pacts' do not receive the same legal recognition as collective agreements.

\#3\# The Popular Party won the 1996 elections, bringing to an end twelve years of socialist rule.

\#4\# The majority of redundancies in Spain are a result of temporary contracts coming to an end. Workers with permanent contracts may be made redundant on economic, technological or organisational grounds, although this is not the most widely-used method of dismissal (it is virtually only found in mediumsized and large companies). Workers may also be made redundant for disciplinary reasons. In this case, if the worker does not accept the reasons 
given, the matter is resolved by an industrial tribunal. If the tribunal finds in favour of the worker, the company may choose still to go ahead with the redundancy on payment of a sum which is usually equivalent to 45 days' pay for every year worked, but which has been reduced to 33 days' pay per year worked in the case of the new contracts created under the AIEE. Disciplinary reasons are very widely used as grounds for dismissal in Spain.

\#5\# Possibly the most important agreement is the collective agreement for the textiles industry, in which employers and unions agreed (in April 2000) on a system for regulating 'out-of-house' work (i.e. people working from home), the use of temporary employment agencies, and subcontracting. The extent to which workers' representatives are kept informed about such activities and are able to monitor them has been increased significantly. Given the dispersed nature of the textiles sector, the collective agreement establishes that accredited trade union officials can act as workers' representatives within textiles companies with a view to monitoring employment trends and ensuring that the collective agreement is implemented at all levels.

\#6\# In the year 2000 , for example, $45 \%$ of workers were covered by collective agreements which allowed working hours to be unevenly distributed over the course of the year, whereas this kind of clause was almost unheard-of just a few years previously (Economic and Social Council 2001: 400-401). 